\title{
Selected Paper Abstracts
}

\section{Annual Meetings}

TITLE: Economic Issues in Agricultural Finance and Banking (Moderator: Gregg Ibendahl, Mississippi State University)

Evaluating Agricultural Banking Efficiency Using the Fourier Functional Form Yingzhuo Yu, Cesar Escalante, University of Georgia, and Xiaohui Deng, California State University

This study applied the Fourier flexible functional form and tested the validity of the Translog cost functional form for the banking industry. Meanwhile, the study extended four different cost efficiency measures. By evaluating these efficiency measures, banks will identify sources of inefficiency to improve their operational policies, procedures, and performance.

Farm Credit Employees' Perceptions of Loan Business Relative to Different Types of Borrowers Brian Briggeman and Philip Kenkel, Oklahoma State University

Characteristics and potential loan volume growth of different borrower types is assessed relative to the opinions of Oklahoma Farm Credit senior officials and loan officers. Senior officials are more positive relative to the characteristics of nontraditional borrowers; however, both agree these borrowers provide the best opportunity for loan growth.

Financial Impacts of Regional Differences in Dairies Brian Herbst, James Richardson, Joe Outlaw, and David P. Anderson, Texas A\&M University

The sensitivity of net cash farm income to changes in selected production variables, out- put prices, and input costs varies significantly across representative U.S. dairies. Different regions of the country were affected differently by changes to production and prices.

Optimal Machinery Replacement under Accelerated Depreciation Gregory Ibendahl, Mississippi State University, and Jonanthan Norvell, University of Illinois

Accelerated depreciation laws seem to be designed to help stimulate the economy by encouraging farmers to purchase more machinery and to replace machinery more often. This paper tests for the optimal replacement age and finds that accelerated deprecation laws appear to help farmers. However, the optimal year to replace is not different.

Record-Keeping Technology Adoption in the Louisiana Dairy Industry Elisabeth Grisham, and Jeff Gillespie, Louisiana State University

Louisiana farmers were surveyed to determine their adoption of information and record-keeping technologies, including the Internet, DHIA, use of financial measures, and frequency of use of computerized records. Factors influencing adoption included having a family successor, overall technology adoption propensity, diversification, off-farm income, college degree, and others.

TITLE: Importance and Implications of Farm Programs (Moderator: Tim Woods, University of Kentucky)

Choice Models in Policy Analysis Hector $O$. Zapata, Pramd Sambidi, and Elizabeth $A$. Dufour, Louisiana State University 
The survey article provides a selected review of studies on econometric choice modeling of different agricultural policy issues. The study discusses how one model is preferred over the other and in what circumstances a particular model should be used.

Economic Analysis of Water Conservation Policies in the Texas Panhandle Robert Taylor, Lal K. Almas, and W. Arden Colette, West Texas A\&M University

Because of declining water availability from the Ogallala Aquifer, management policy alternatives for extending aquifer life to sustain Texas Panhandle rural economies are evaluated. The study concludes that water conservation policies for the region significantly affect crop mix, resource usage, and net present value of farm profits over a 60-year planning horizon.

\section{Evaluating a Proposed Modification to Federal Crop Insurance Shuqiong Ling, University of Georgia, Xiaohui Deng, California State Uni- versity, and Barry J. Barnett, University of Georgia}

A proposed modification to the Federal Crop Insurance Program would allow crop producers to simultaneously purchase farmlevel crop insurance and supplemental countylevel crop insurance. This study evaluates this proposal for representative Georgia cotton farms. The goal is to test whether the additional risk protection provided is worth the additional cost.

Postbuyout Burley Tobacco Production and Trends in the Traditional Burley Regions of Tennessee, North Carolina, and Virginia Kelly Tiller and LaKeya Jones, University of Tennessee

The 2004 federal tobacco buyout ended the longstanding tobacco quota and price support programs, and also eliminated all tobacco reporting requirements. Producers are adjusting to the free market with scant information.
The 2006 Burley Tobacco Survey provides an initial glimpse of postbuyout burley tobacco production, trends, challenges, and expectations.

The Effect of Changing Government Subsidy Programs: An Analysis of Revenue at the Farm Level Sarah Thomas, Keith Coble, and J. Corey Miller, Mississippi State University

Producer revenue is simultaneously simulated for several hundred county-specific representative farms. The effects of current and alternative commodity programs are analyzed. In particular, two variations of revenue-triggered programs similar to plans proposed by the National Corn Growers Association are evaluated.

TITLE: Efficiency and Environmental Concerns in Fisheries and Wetlands Management (Moderator: Rita Carreira, University of Arkansas)

Economic and Physical Measures of Efficiency: The Case of the Gulf of Mexico Grouper Fishery Hamady Diop, Walter Keithly, Jr., and Richard Kazmierczak, Jr., Louisiana State University, and Assane Diagne, Gulf of Mexico Fisheries Management Council

Results indicate that both long- and vertical liners experience random shocks as well as inefficiency. The longliners' vessel efficiency is increasing over time, and crew size and effort are positively correlated with efficiency. The vertical liners' efficiencies are also positively associated with crew size as the vessels become specialized in grouper targeting.

Optimal Investment in Prevention and Control of a Potential Invader: The Case of Zebra Mussels in Florida Waterways Damian Adams, Donna J. Lee, and Frederick Rossi, University of Florida

The probability of a severe infestation ranges from $2 \%$ to $98 \%$ depending on in- 
vestment in monitoring, prevention, and response technology. Given the estimated potential for economic damages, preliminary results indicate that prudent investment in prevention and early response net a present value net return of $\$ 10$ million over 20 years.

Public Health and the Economic Impacts Generated by Persistent, Bioaccumulative, and Toxic (PBT) Contaminants in U.S. Fisheries Tina Willson and Richard Kazmierczak, Jr., Louisiana State University

Widely dispersed information from the public health, economic, and fisheries management literature is synthesized to examine the impacts of PBT contamination, including current and potential impacts on public health and the ongoing economic impacts this contamination has on the U.S. fishing industry.

The Economic Potential of Composting Breeder and Pullet Litter with Egg Shell Waste Nathan Kemper, H.L. Goodwin, Jr., and Sandra Hamm, University of Arkansas

Expansion of the wastes coordinated by the Ozark Poultry Litter Bank is needed. This study examined a method of combining low value poultry wastes to produce compost. Analyses of four compost blends and two hypothetical production systems provide entrepreneurs with the production and financial information to make informed decisions.

TITLE: Livestock Production Economics (Moderator: Joey Mehlhorn, University of Tennessee at Martin)

Dairy Resource Management: A Comparison of Conventional and Pasture-Based Systems Richard Nehring, USDA-ERS, Jeff Gillespie, Louisiana State University, and Erik O'Donoghue and Carmen Sandretto, USDA-ERS

U.S. dairy production experienced rapid and significant change from 1993-2005. These sector trends were tracked, performance measures (scale and technical efficiency and returns on assets) were estimated, and comparisons of relative economic performance were made for conventional and pasture-based dairy farms using data from the USDA's Agricultural Resource Management Survey.

Long-Term Profitability of Animal Manure Using Optimal Nitrogen Application Rate Seong Cheol Park, Art Stoecker, Jeffory Hattey, and Jason Turner, Oklahoma State University

Dynamic optimization was used to compare the NPV of manure and ammonium fertilizers on irrigated corn. Yield, soil residual nitrogen, and $\mathrm{pH}$ functions were estimated from a six-year experiment in Oklahoma. Results show that given prices of corn and nitrogen fertilizer, animal manures provide a higher NPV of return than ammonia fertilizer.

Precision Feeding in Dairy Ration Cost Minimization under Producer's Risk Management Juma Salim and Carl Dillon, University of Kentucky

The biophysical simulation data from Cornell Net Carbohydrate and Protein System were used in nonlinear programming model for least cost ration incorporating ingredient, nutrient, and price variations. Precision feeding practice is indicated to have a lower mean cost ration than whole herd feeding in terms of ration cost.

TITLE: Optimal Farming Strategies (Moderator: Siddhartha Dasgupta, Kentucky State University)

Adoption of Conservation-Tillage Practices in Cotton Production Swagata Banerjee and Steven W. Martin, Mississippi State University, Roland K. Roberts and James A. Larson, University of Tennessee, Robert Hogan, Jr., University of Arkansas, Jason L. Johnson, Texas A\&M University, Kenneth W. Paxton, Louisiana State University, and Jeanne $M$. Reeves, Cotton Incorporated 
Simultaneous adoption of conservationtillage practices and herbicide-resistant and/ or stacked-gene seed in cotton production was studied using a two-equation system of logit models, and compared with single-equation logits for each technology adoption. Simultaneity and single-equation estimation methods provided similar results for the tillage equation, but differences were observed with the seed use equation.

\section{Can Catfish Aquaculture Be Profitable in Farm Ponds? Siddhartha Dasgupta, William Wurts, and Robert Durborow, Kentucky State Univer- sity}

Extensive catfish farming can be performed using farm ponds. A mathematical model of this system showed that the optimal strategy would be to stock fish at 1,200 head/ac/yr, leading to a $1,198 \mathrm{lb} / \mathrm{ac}$ yield, at a breakeven price of $\$ 0.82 / \mathrm{lb}$. Hence, extensive aquaculture is both feasible and profitable in farm ponds.

Optimal Harvest Time of Florida Valencia Oranges to Maximize Grower Returns Jacob Searcy, Fritz Roka, and Thomas Spreen, University of Florida

Research goals are to estimate the optimal harvest time of Florida Valencia oranges for Florida growers and calculate the economic consequences of harvesting inside or outside the optimal window. Determining the optimal fruit harvest time will help the industry anticipate how mechanical harvesting may affect deviations from this optimum.

The Effect of Early versus Normal Calf Weaning on Feedlot Performance and Herd Management: A Cross-Discipline Case Study Scott Fausti, South Dakota State University, Doug Landblom, North Dakota State University, Particia Johnson, Martin Beutler, Roger Gates, and Robin Salverson, South Dakota State University, Hubert Patterson, Padlock Ranch, and Steve Paisley, University of Wyoming
A study of early versus normal weaning of calves concludes that early weaning improves feedlot production efficiency, reducing per day and per pound feedlot production costs. Early weaned steers finished higher, thus feedlot profitability was not affected. Early weaning has a positive affect on cow health and pasture utilization rates.

TITLE: Economics of Livestock Enterprises (Moderator: Juma Salim, University of Kentucky)

Economic Analysis of a Traveling Gun for Feed Yard Dust Suppression Stephen Amosson, Fran Bretz, and Leon New, Texas A\&M University, and Lal $K$. Almas, West Texas A\&M University

Dust created in feed yards can adversely affect cattle performance. Dust suppression can be accomplished by moistening pen surfaces with traveling gun sprinklers, solidset sprinklers, and water trucks. This study specifically addresses the fixed and operational costs associated with a traveling gun sprinkler system for various sized feed yards.

The Economics of Rotational Grazing in the Gulf Coast Region: Costs, Returns, and Labor Considerations Jeffrey Gillespie and Wayne Wyat, Louisiana State University, Brad Venuto, USDA-ARS, and David Blouin and Robert Boucher, Louisiana State University

Labor and profitability associated with continuous grazing at three stocking rates and rotational grazing at a high stocking rate are compared. Profits are lowest for low stocking rate continuous grazing and high stocking rate rotational grazing. Labor is greatest on per-acre and per-cow bases with rotational grazing.

\footnotetext{
Simulated Analysis of Drought's Impact on Different Cow-Calf Production Systems M.C. Stockton and R.K. Wilson, University of $\mathrm{Ne}$ braska
} 
Five representative firm-level stochastic simulation models were constructed using historical production cost, cattle prices, weather information, and scientifically collected production data from the Gundmendson Sandhills Laboratory operated by the University of Nebraska. The 500 iterative results indicate inclusion of crop residual grazing as a viable drought mitigation tool.

\section{The Value of Pregnancy Testing Beef Cows Billy Cook, Jon Biermacher, and Dan Childs, Samuel Roberts Noble Foundation}

Less than half of cow and calf producers in south-central Oklahoma and north-central Texas utilize pregnancy testing. The objective was to illustrate to beef cattle producers the effect that pregnancy testing and the subsequent adoption of an effective culling practice on first-time open cows has on net profitability of the cow-calf enterprise.

TITLE: Livestock Trade Issues (Moderator: Jaime Malaga, Texas Tech University)

Assessment of Import Restrictions on the U.S. Meat and Livestock Markets: An Application to the Case of Discovery of BSE on Canadian Cattle Tullaya Boonsaeng, University of Georgia, and Michael Wohlgenant, North Carolina State University

This study investigates the impact of the discovery of BSE in Canadian cattle on the imported and domestic demand for livestock and meat in the United States. A multimarket partial equilibrium model simulates the effects of policy-induced shifts in quantities of Canadian imports. Our simulation results predict small effects on cattle.

Modeling the Structural Change in American Frozen Catfish Fillet Demand: An Analysis of Country of Origin Labeling and the Implementation of an Import Tariff Lawton Nalley, Kansas State University
Given the recent trade disputes between the United States and Vietnam on catfish, this paper uses the Almost Ideal Demand System to analyze two issues (1) The effect of the implantation of mandatory country of origin labeling of Vietnamese fish and (2) the effect of a tariff on Vietnamese basa.

TITLE: Market Niches and Perceptions (Moderator: Safdar Muhammad, Tennessee State University)

Does Consumer Knowledge Affect Meat Consumption in the United States? Christopher Davis, USDA-ERS, Steven Yen, University of Tennessee, and Biing-Hwan Lin, USDA-ERS

We investigate the roles of consumer knowledge and sociodemographic factors in the consumption of meat products at home and away from home. Results indicate that health knowledge decreases consumption of beef and pork, and increases consumption of poultry at home and away from home but does not affect fish consumption.

Factors Affecting Demand for Branded Beef Steve Martinez, USDA-ERS, Roger Hanagriff and Michael Lau, Sam Houston State University, and Michael Harris, USDA-ERS

This paper finds that branded fresh beef expenditures increased from $20.8 \%$ in 1998 to $28.6 \%$ in 2004 for all fresh beef expenditures. In addition, geographic location, household income, household race, and household size were found to affect the likelihood of branded fresh beef purchases in 2004 .

Manufacturer Perceptions of U.S. PeanutsResults of a Recent Survey Lisa House, Ron Ward, and Julie Johnson, University of Florida, and Marshall Lamb, USDA-ARS

In 2002, a new farm bill radically changed the U.S. peanut industry by eliminating the marketing quota system, requiring the industry to adjust to a more uncertain, marketoriented environment. This paper reports 
results from a survey of peanut manufacturers in nine countries, identifying their peanut import habits and preferences.

Positioning Cotton in the Market for Quality: An Application of Market Segmentation for West Texas Sangnyeol Jung and Conrad Lyford, Texas Tech University

This study provides guidance for cotton marketing efforts by determining major market segments with quality thresholds for West Texas. Given its present quality performance, great potential segments are from higher-end international segments with significant value added. Moreover, the potential to serve these market segments is growing with improvements in production technology.

\section{TITLE: Comparable Approaches to Estima-} tion (Moderator: Sung Chul No, Southern University and A\&M College)

Relative Importance of Environmental Attributes Using Logistic Regression Carlos Carpio, Clemson University, and Olga Sydorovich and Michele Marra, North Carolina State University

The relative importance of attributes in the discrete choice setting under four methods is investigated. Empirical application involves the development of a risk index system for individual herbicides combining different human and environmental risks. The values of the pesticide risk indices are found to be consistent across the different methods

TITLE: Rural Development Issues and Opportunities (Moderator: Jean-Marc Gandonou, University of Kentucky)

Community Development and Local Social Capital Jeffrey Jordan, University of Georgia, and Abdul Munasib, Oklahoma State University

The potential of local economic development to explain the variation in social capital across various geographical clusters in the state of Georgia is studied. Findings show that even after considering various demographic and economic characteristics, this explains the variation in a number of social capital levels across these clusters.

Determinants of Youth Poverty: A Zip Code Analysis Kaustav Misra and David Debertin, University of Kentucky

Estimation of Gini coefficients for various age groups indicates that the Kentucky youth population is at risk. The paper determines the factors affecting youth poverty, employing zip code data. Analysis of outcomes provides suggestions for the policymakers to limit youth poverty in Kentucky.

Is Attracting Retirees a Sustainable Rural Economic Development Policy? Biswaranjan Das and Daniel Rainey, University of Arkansas

An economic impact analysis was conducted in two rural counties in northwest Arkansas to observe effects of hypothetical retiree in-migration as a sustainable economic development policy. The analysis reveals economic benefits with varying impacts and additional socioeconomic costs on both counties. The policy has the potential for being sustainable in the long term.

Assessing Sustainability of Agricultural Systems: Evidence from a Conjoint Choice Survey Olha Sydorovych and Ada Wossink, North Carolina State University

This study identifies a list of economic, social, and ecological agricultural sustainability attributes based on experts' opinions. Next, the attributes are used in a conjoint choice experiment that enables direct extraction of the relative impact of the attributes and attribute levels on individual respondents' perception of overall sustainability.

TITLE: Economic Issues in Value-Added Agribusiness (Moderator: Wes Harrison, Louisiana State University) 
Crawfish Peeler Preferences for the Adoption of a Potential Crawfish Peeling Machine: A Conjoint Analysis Darius Lewis and Jeff Gillespie, Louisiana State University

Thirty crawfish processors' preferences for hypothetical crawfish peeling machines are evaluated using conjoint analysis. Deveining is the most important attribute, with fat retention, individual handling of crawfish, and backstrap retention being roughly equal in importance. Whether the machine is owned or leased is the least important attribute.

Feasibility of Machinery Cooperatives in the Southern Plains Region Garret Long and Philip Kenkel, Oklahoma State University

This is a comparison of machinery ownership costs for individuals and cooperatives. By looking at various complements of equipment, we can see the potential for cost savings through machinery cooperatives. Specifically these savings can be seen in farming operations that require higher capital investment, such as in no-till operations.

Soy Food Consumption Pattern: Effects of Product Attributes and Household Characteristics Arbindra Rimal, Missouri State University, and Wanki Moon and Siva Balasubramanian, Southern Illinois University

Effects of perceived attributes of soy foods on the consumption of tofu, vegetable burgers, soy milk, soy supplements, meat substitutes, and soy cheese were evaluated. Attributes included convenience, health benefits, and taste. While health benefits influenced the decision to consume, products like tofu could be marketed based on taste and convenience.

The Impacts of Market Structure and Contracts on Agricultural Markets Darren Hudson, John Anderson, Ardian Harri, and Steve Turner, Mississippi State University

Experimental markets were used to isolate the effects of market structure and contract design on market outcomes. Preliminary results suggest that market structure drives outcomes, and not necessarily contract design. Future research will replicate experiments and add dimensions of market information.

TITLE: U.S. Economy, International Trade, and Farm and Labor Policy (Moderator: Ashfaqul Babool, University of Kentucky)

BSE and the U.S. Economy: Input-Output Model Perspective Osei-Agyeman Yeboah, North Carolina A\&T State University, Ellene Kedebe, Tuskegee University, Victor Ofori-Boadu, North Carolina A\&T State University, and Albert J. Allen, Mississippi State University

The potential impact of a BSE outbreak on the U.S. economy is modeled in input-output setting using the 2002 US IMPLAN data. The outbreak would hurt the U.S. beef industry, other agriculturally related industries, and the rest of the general economy. The worst effects occur in the beef cattle and farming industries.

Implications of Proposed Immigration Reform for the U.S. Farm Labor Market Lurleen Walters, Robert Emerson, and Nobuyuki Iwai, University of Florida

Specialty crop agriculture may be affected by immigration reform given that most farm workers are foreign-born and unauthorized for U.S. employment. Controlling for selection on legal status and job type according to skill level, this research examines the wage effects for workers with different characteristics in the United States and the South.

The Impact of Competition Policy on Production and Export Competitiveness: A Perspective from Agrifood Processing Ashfaqul Babool and Michael Reed, University of Kentucky, Mia Mikic, United Nations Economic and Social Commission for Asia and the Pacific, and Sayed Saghaian, University of Kentucky

This study tests the hypothesis that competition policy positively affects a country's 
production and export competitiveness. The results show that competition policy has a significantly positive impact on manufacturing production. The results also show that exports for both total manufacturing and food manufacturing are positively related to competition policy.

\section{WTO Impacts on U.S. Rice Producing House-} holds Roman Keeney and Jayson Beckman, Purdue University

We investigate distributional impacts of WTO reforms on U.S. rice producers. Model results show that rice producer's household income is very sensitive to the amount of market access achieved in export markets and the depth of subsidy cuts in the United States, largely explaining the U.S. negotiating position in the WTO.

TITLE: Issues in Land Use, Recreational, and Wildlife Management (Moderator: James Henderson, Louisiana State University)

Determinants of Demand for Participation in Wildlife Hunting: A County Level Analysis Neelam Poudyal and Seong-Hoon Cho, University of Tennessee, and Michael Bowker, USDA-Forest Service

We developed an economic demand model of wildlife hunting and found that sociodemographic and ecological characteristics of a county are its strong predictors. Result shows that the hunting is not popular among the younger generation; promoting hunting clubs and lease-hunting, recruiting young hunters could be effective policy considerations for retaining and promoting hunting.

How Much Influence Does Recreation Have on Agricultural Land Prices? Pam Guiling, Wade Brorsen, and Damona Doye, Oklahoma State University

Time-series data for Oklahoma agricultural land sales from 2001-2005 are analyzed to measure the impacts of recreation and urban- ization. Recreational variables such as deer harvest per county and variables depicting urban influence were found to have positive significant impacts on land values while tract size had a negative impact.

Investigating the Potential of Fee-Based Recreation on Private Lands in the Lower Mississippi River Delta James Henderson and Michael A. Dunn, Louisiana State University

This study seeks to determine what characteristics influence landowners' decisions regarding whether to engage in fee-based recreation activities and their choice of organizational form. It also examines how liability concerns and other possible disincentives collectively influence landowners' decisions to grant or not grant access to their lands.

The Role of Stakeholders' Perceptions in Addressing Water Quality Disputes in an Embattled Watershed Jennie Popp and German Rodriguez, University of Arkansas

Preliminary results of a survey of agricultural and nonagricultural stakeholders in the Lincoln Lake Watershed suggests discrepancies exists in different groups' perceptions of water quality, the sources of water pollution, and the roles of local, county, state, and federal officials in meeting water quality objectives.

TITLE: Economic Feasibility and Enterprise Choice (Moderator: Dayton Lambert, University of Tennessee at Knoxville)

Economic Feasibility of Kenaf Production in Three Tennessee Counties Ernest Bazen, Roland $K$. Roberts, and Burton C. English, University of Tennessee

This article seeks to expand current literature by discussing the economic feasibility of growing kenaf within three counties in Tennessee. Results revealed that kenaf would not compete with traditional crops at prices below $\$ 49 /$ ton, while profit-maximizing farmers 
could supply as much as $1,385,700$ tons of kenaf at prices of $\$ 55 /$ ton.

Economic Feasibility of Small Scale Vegetable Production and Retailing in Rural Communities Jon Biermacher, Steve Upson, David Miller, and Dusty Pittman, Samuel Roberts, Foundation

Economic information about the feasibility of producing and retailing vegetables in rural communities is limited. The objectives were to determine actual net return from producing and retailing a mix of produce in a rural community, and to determine if consumers were willing to pay differentiated prices for the locally grown vegetables.

The Role of Goal Structure in Enterprise Selection in U.S. Agriculture Ashok Mishra, USDA-ERS, and Jeff Gillespie, Louisiana State University

This paper addresses the roles of goal structure, location, financial situation, and sociodemographic variables and their influence on farmers' farm enterprise selection decisions. Results suggest the important role of farm succession in beef, dairy, and crop production, contrasted with its lesser role in broiler production relative to generating additional income.

Comparison of Water Allocation Strategies for Wheat Production in the Texas Panhandle $W$. Arden Colette and Lal K. Almas, West Texas A\&M University

The declining availability of irrigation water from the Ogallala aquifer combined with increasing energy costs make irrigation strategies much more critical. Irrigation strategies that maximize returns to irrigation require less water and achieve higher returns than strategies aimed at satisfying $100 \%$ of the crops' evapotranspiration (ET) requirements.

TITLE: Consumers' Choice and Firms' Response (Moderator: Albert E. Myles, Mississippi State University)
A New Taxonomy of Thin Markets John Anderson, Darren Hudson, Ardian Harri, and Steve Turner, Mississippi State University

As nonprice means of pricing goods becomes more common, some cash commodity markets have become residual markets. This paper develops a concept of thin markets that accounts for this dimension of market thinness and proposes a research agenda related to this topic.

\section{Consumer Purchasing Behaviors and Attitudes} toward Shopping at Public Markets in Birmingham, AL Michael Mukiibi and James Bukenya, Alabama A\&M University, Joseph Molnar, Auburn University, Arthur Siaway, Tuskegee University, and L. Rigdon, Auburn University

The paper examines demographic characteristics and purchasing behaviors that might influence consumers' decision to patronize public markets. Data were drawn from 502 potential food shoppers in Birmingham, AL. Logit model results point to several factors including income, education, household size, price, and quality.

Supermarket Price Competition in the DallasFort Worth Fluid Milk Market Benaissa Chidmi, Texas Tech University

This paper estimates the effect of the price war on the fluid milk demand in the DallasFort Worth market and assesses the supermarket pricing conduct through estimating the price-cost margins of the retailers. The findings that supermarket chains in Dallas-Fort Worth market exercise market power and that demand for milk is insensitive to price changes.

Targeting Consumers by Store: The Basis of Increased Sales with Less Advertising David Ubilava and Ken Foster, Purdue University

The conditional logit approach was used to analyze the choice experiment data obtained from the grocery stores and supermarket of 
Tbilisi, GA. Results show that customers' preferences for selected pork attributes in different stores are not the same. So, targeting customers by store can be a beneficial marketing tool for pork suppliers.

The Dual Nature of Choice: When Consumers Prefer Less to More Jayson Lusk and F. Bailey Norwood, Oklahoma State University

This paper reports results from experiments designed to further investigate the excessive-choice effect, where less choice is preferred to more. Results show that the excessive-choice effect indeed exists for some people, but on average people prefer greater choice.

TITLE: Crop Production Economics (Moderator: Rob Hogan, University of Arkansas)

Genetically Modified Crops and Labor Savings in U.S. Crop Production Justin Gardner and Carl Nelson, University of Illinois

In spite of widespread adoption, there is mixed evidence as to whether adopting genetically modified (GM) crops increases farm welfare. One possible reason for widespread adoption is labor savings. Using a treatment effect model, we estimate the labor savings associated with adopting a GM crop.

Optimizing Dual Interdependent Products from a Single Crop Karen Taylor and Francis $M$. Epplin, Oklahoma State University

The objective of the research is to determine the optimal grazing termination date that maximizes expected net returns from dual-purpose winter wheat production. Preliminary results indicate that grazing should be terminated at or before first hollow stem to generate the highest expected net returns in a dual-purpose winter wheat production enterprise.

Suitability for Global Maize Production: A Methodology Based on Spatial Analysis Xiang- dong Shi, Texas A\&M University, and Robert L. Thompson, University of Illinois

A methodology based on spatial analysis is proposed to investigate suitability of a crop, and then applied to analyzing the suitability for global maize production. The suitable and unsuitable maize cultivated regions are given based on the analysis, and maize cultivated regions sensitive to economic incentive are also illustrated and discussed.

The Impacts of GM Seed Technology on Cotton: Cost of Production in Mississippi, 1996-2005 W. Michael Thompson, II, John Anderson, Gregg Ibendahl, and Darren Hudson, Mississippi State University

The rapid adoption of genetically modified (GM) cotton varieties in Mississippi has allowed producers to alter certain production practices because of added benefits. This study analyses some of the effects of adoption of GM varieties in Mississippi by comparing production functions from 1996 and 2005.

TITLE: Futures Markets and Agribusiness Risks (Moderator: Jason Hartell, University of Kentucky)

Nonparametric Analysis of ENSO Impacts on Yield Distributions: Implications for GRP Contract Design Denis Nadolnyak and James Novak, Auburn University, Dmitry Vedenov and Joel Paz, University of Georgia, Clyde Fraisse, University of Florida, and Gerrit Hoogenboom, University of Georgia

The paper reports preliminary results of nonparametric analysis of historical and cropmodel generated peanut yield series in southwest Georgia. The results suggest ENSO phase dependent differences in yield distributions that are similar for both the simulated and actual series. The differences are magnified in GRP insurance premiums.

Producer-Level Hedging Effectiveness of Class III Milk Futures Jonathan Schneider, Dwight 
Sanders, and Ira Altman, Southern Illinois University

Mailbox milk prices from a representative dairy operation in Illinois are used to gauge the farm-level hedging effectiveness of Class III milk futures. The results indicate a hedge ratio of 0.85 can reduce price risk by over $90 \%$. The importance of seasonal basis components is highlighted.

The Efficiency of the U.S. Cotton Futures Market (1986-2006): A Test for Normal Backwardation and Identification of Economic Indicators Marissa Chavez, Victoria Salin, and John Robinson, Texas A\&M University

The cotton futures market was analyzed to determine pricing patterns and explain pricing with an equilibrium asset pricing framework. Results are consistent with the efficient market hypothesis over the long run. Pricing trends existed within contracts and by seasons. Cotton futures do not show significant risk premiums over other financial assets.

\section{TITLE: Evaluations in Renewable Energy} (Moderator: Ernest Bazen, University of Tennessee at Knoxville)

Days Available for Harvesting Lignocellulosic Biomass Seonghuyk Hwang and Francis $M$. Epplin, Oklahoma State University

A reasonably precise estimate of the number of harvest days is necessary to determine the investment in harvest machines required to support a lignocellulosic biorefinery. This study was undertaken to determine probability distributions for the number of suitable field work days per month for harvesting perennial grasses such as switchgrass.

The Impact of Biofuel Production on Crop Production in the Southern Plains Holly Ragan, and Phil Kenkel, Oklahoma State University

The objective of the study is to determine how grain-based ethanol, cellulosic-based eth- anol, and biodiesel production could influence cropping patterns in the southern plains. The study analyzes current and potential biofuel crop production and projects' cropping changes at various biofuel prices.

Yield and Production Costs for Three Potential Dedicated Energy Crops in Mississippi and Oklahoma Environments David Busby and Saleem Shaik, Mississippi State University, Angelina Martins and Francis Epplin, Oklahoma State University, Randall Little, Mississippi State University, Charles Talaiferro, Oklahoma State University, Brian Baldwin, Mississippi State University, and Seonghuyk Hwang, Oklahoma State University

The objective of this paper is to determine production costs of switchgrass, eastern gammagrass, and giant miscanthus using Mississippi and Oklahoma data. Production costs were computed using a standard enterprise budgeting approach by species and method of harvest. Results indicate cost difference across species and method of harvest.

TITLE: Precision Agriculture and Water Use (Moderator: Carl Dillon, University of Kentucky)

Bioeconomic Modeling to Assess Economic and Water Quality Impacts of Land Use Change Gandhi Raj Bhattarai, Diane Hite, Puneet Srivastava, and Upton Hatch, Auburn University

Changes in water quality and agricultural and forest revenues due to land use changes are compared. A biophysical model estimates the effect in nitrogen and phosphorus runoff and sediment deposition. The results are combined with farm enterprise budgets to estimate the economic returns resulting from land use changes.

Factors Influencing Adoption of Remotely Sensed Imagery for Site-Specific Management in Cotton Production James Larson, Roland $K$. Roberts, and Burton C. English, University of Tennessee, Sherry L. Larkin, University of 
Florida, Michele C. Marra, North Carolina State University, Steven W. Martin, Mississippi State University, Kenneth W. Paxton, Louisiana State University, and Jeanne $M$. Reeves, Cotton Incorporated

This research evaluated the factors that influenced cotton producers to adopt remote sensing for variable rate application of inputs. Farmers who were younger and more highly educated, had a larger farm operation, and were more technologically savvy were more likely to have adopted remote sensing.

New Precision Agriculture Technology Adoption for Dealers under Imperfect Market Haili Jia, University of Kentucky

Factors that affect agribusiness firms' investment decision on new precision agriculture techniques are identified, and the real option model is used to derive both the lead and follow-on investment threshold. Results show the initial precision agriculture investment cost will have the most significant effect on firms' adoption threshold.

Precision Timing and Spatial Allocation of Economic Fertilizer Application Jean-Marc Gandonou and Carl Dillon, University of Kentucky

Recent increases in fertilizer price have resulted in increased production cost for farmers. This paper examines the impact of price variability on production decisions such as the optimal fertilizer levels by spatial characteristics, optimal timing, and frequency of application, and crop acreage reallocation in an expected value variance modeling framework.

Reducing Irrigation Water Demand with Cotton Production in West Texas Lal Almas and W. Arden Colette, West Texas A\&M University, and Patrick Warminski, Panhandle Groundwater Conservation District

Because of declining water availability from the Ogallala Aquifer and increasing pumping costs, irrigation management options for cotton are analyzed. The study concludes that supplemental irrigation while meeting crop ET requirements is the most profitable option. Switching from corn to cotton production may reduce irrigation water demand in the region.

TITLE: Impacts of Higher Energy Costs on Agriculture and Renewable Energy (Moderator: Mike Salassi, Louisiana State University)

Can the U.S. Ethanol Industry Compete in the Alternative Fuels' Market Zibin Zhang, Dimitry Vedenov, and Michael Wetzstein, University of Georgia

Previously, ethanol was unable to expand nationally. It was dominated by MTBE until states banned MTBE. A limit-pricing hypothesis may explain limited ethanol entry. As a test, a SVAR model is developed. The results support the hypothesis and suggest corn-based ethanol limits U.S. ethanol's ability to compete with sugarcane-based ethanol.

Contracting for Biomass: Supply Chain Strategies for Renewable Energy Ira Altman, Southern Illinois University, Chris Boessen, University of Missouri, and Dwight Sanders, Southern Illinois University

An organizational perspective is taken in analyzing the general case of the biomass exchange and the specific case of the Iogen Corporation as it attempts to commercialize their cellulose ethanol technology. An example contract is examined in detail and compared to current straw and hay supply chain systems.

Economic Impacts of Ethanol Production in Georgia Archie Flanders, Audrey Luke-Morgan, George Shumaker, and John McKissick, University of Georgia

Capital costs to construct a conventional ethanol plant producing 100 million gallons per year are $\$ 170.593$ million. Average annual 
net returns average $\$ 59.216$ million with a $1 \%$ chance of annual net returns less than $\$ 0$. Ethanol production stimulates total economic output of $\$ 314.221$ million in the Georgia economy.

Influence of the Natural Gas Price on the Ammonia Price, 2000 to 2006 Wen-yuan Huang, Economic Research Service

An equilibrium error-correction model is used in the analysis. With respect to the natural gas price, the estimated long-run equilibrium ammonia price elasticity is 0.79 , the short-run elasticity of the ratio of price changes is 0.25 , and the adjustment for the disruption from the ammonia equilibrium price is $23 \%$.

Availability of Poultry Litter as an Alternative Energy Feedstock: The Case for Mississippi Andy Whittington, Mississippi State University

This study will examine the poultry industry in a nine-county area in Mississippi, and estimate the availability of poultry litter as a feedstock for the production of energy and ethanol. The study will use an $X, Y$ coordinate model to locate a production facility that minimizes transportation costs.

TITLE: Options, Volatility, and Cointegration in Prices (Moderator: Joselito K. Estrada, Texas A\&M University at Galveston)

\section{Accuracy of Implied Volatility Approximations Using "Nearest-to-the-Money" Option Pre- miums Olga Isengildina-Massa, Charles E. Curtis, Jr., William Bridges, and Minhuan Nian, Clemson University}

The Black-Scholes formula is widely used to estimate implied volatility, but requires numeric search to obtain a solution. Numerous approximations to the B-S formula have been proposed. This study identifies and tests the accuracy of these approximation methods using call only and put-call average elicitation of an implied volatility estimate.
Forecasting U.S. Shelled Pecan Prices: A Cointegration Approach Mohammed Ibrahim, Fort Valley State University, and Wojciech J. Florkowski, University of Georgia

This paper investigates the usefulness of the cointegration technique in forecasting possibly cointegrated variables. ARIMA and cointegration methods are used to make forecasts with monthly data. Results suggest that pecan inventories and pecan prices are nonstationary and cointegrated. The cointegration methods outperformed the ARIMA model only at longer periods.

Is There a "Right" Time to Buy Options Preharvest? Charles E. Curtis, Jr., Olga Isengildina-Massa, and Andrew Hummel, Clemson University

Variables that affect the option premium levels are studied to identify a period that would be considered "preferred" for the purchase of a December put option contract for corn and cotton. Results suggest that March may be a preferred time to purchase December cotton and corn put options.

TITLE: Issues in Resource Management (Moderator: Krishna Paudel, Louisiana State University)

Calibrating Online Survey Sample for Economic Impact Analysis Nirmala Devkota, Krishna Paudel, J. Matthew Fannin, Lary $M$. Hall, and Rex H. Caffey, Louisiana State University

Online surveys have emerged as a low-cost data collection approach in empirical researches; however, the validity of the data remains questionable. Stochastic frontier estimation results suggested the presence of inefficiency on online surveys. Analysis was extended to estimate economic impact of nature-based recreation on a local economy.

Consumer Willingness-to-Pay for Green Energy: Results from Focus Groups Patricia Duffy, 
Diane Hite, David Bransby, and Christa Slaton, Auburn University

To discover if consumers are willing to pay surcharges for "green energy," the Alabama Department of Agriculture and Industries hosted focus groups at four locations in Alabama. Consumers were willing to pay a premium in line with the costs, but most did not have much information about green energy.

Coprocessed Poultry Litter and Dewatered Municipal Biosolids: Feasibilty as an Alternative Management Approach for Surplus Waste Andrew Armstrong, H.L. Goodwin, Jr., and Sandra Hamm, University of Arkansas

Neither poultry litter nor dewatered municipal solids (DMB) currently have economically sustainable utilization options that are also environmentally sustainable. The purpose of this research is to investigate the appropriateness of blending poultry litter and DMB as a sustainable way to utilize these products for use in agricultural practices in a cost efficient manner.

TITLE: Rural Development Tools (Moderator: Carlos Carpio, Clemson University)

New Estimation Strategies for Demand Threshold Models in the Southern United States Junpyo Hong and J. Matthew Fannin, Louisiana State University

This paper estimates demand threshold models using both first generation log-log models and second generation Tobit models to zip code areas in the southern United States. Results of own-place demographic and economic variables were consistent with previous studies but impacts of neighboring zip codes contrasted previous studies.

Property Tax Lids and the Effect on Kansas Job D. Springer, Samuel Roberts Noble Foundation, Aaron K. Lusby, Louisiana Tech
University, and John Leatherman and Allen Featherstone, Kansas State University

Cross-sectional time series data in a partial adjustment model examine local government behavior under an aggregate property tax levy limit and under Truth in Taxation in Kansas. Results indicate that the aggregate levy limit would have continued to restrict property tax revenue and spending had it not been replaced.

TITLE: Willingness-to-Pay/Accept and Food Labeling (Moderator: Albert J. Allen, Mississippi State University)

Comparing Willingness-to-Pay Estimates from Experimental Auctions with Mailed Surveys Incorporating Cheap Talk Eve Froelich and Jared Carlberg, University of Manitoba

Willingness-to-pay (WTP) results from experimental auctions are compared with those from cheap-talk and conventional surveys for branded beef products in Canada. It is found that while the cheap-talk survey appears to mitigate hypothetical bias compared with the conventional survey, cheaptalk survey WTP remains higher than that in experimental auctions.

Some Problems in Estimating Willingness-to-Pay with Contingent Valuation Surveys: Case for Consumer Acceptance of Genetically Modified Food Naoya Kaneko, University of Georgia, and Wen S. Chern, Ohio State University

This paper reports results from a U.S. national telephone survey on genetically modified foods. The objectives of this paper are to determine the effect of "indifference" response on the estimate of willingness-to-pay and to test the assumption of common marginal utility of income among respondents.

The Demand for Oysters in the United States: The Importance of Origin and Mandatory Warning Labels Cheikhna Dedah, Walter Keithly, Jr., and Hamady Diop, Louisiana State University 
In 1991, mandatory warning labels were imposed on the sale of oysters harvested from the Gulf of Mexico. Using an IAIDS model, this paper investigates the impact of these labels on the demand for Gulf product as well as related oyster products (the Chesapeake, the Pacific, and imports).

\section{UK Consumers' Willingness-to-Accept (WTA)} GM Food Wanki Moon, Southern Illinois University, Arbindra Rimal, Missouri State University, and Siva Balasubramanian, Southern Illinois University

Our study uses contingent valuation survey data (WTA and WTP) collected in the UK to examine consumers' behavioral intention with regard to GM food. In particular, we characterize respondents who selected "Don't Know" and "Protest" options in WTP questions in terms of what they would do when offered a discount for GM food.

TITLE: Times of Change and Innovation (Moderator: Carl Dillon, University of Kentucky)

An Intersector Impact of Hurricanes Katrina and Rita on the Agribusiness Industry in Mississippi Albert E. Myles, Albert J. Allen, and Saleem Shaik, Mississippi State University

This study evaluates the impact of hurricanes Katrina and Rita on the agribusiness industry and related sectors in Mississippi. Input-output analysis was used to determine the economic impact of these disasters on the Mississippi agribusiness sector and related sectors in the state's economy.

Cost Sensitivity Analysis on the Optimal Location of Technology Providers in Kentucky Jordan Shockley, Sayed Saghaian, and Carl Dillon, University of Kentucky

A warehouse location model was utilized to expand upon previous research. The aim was to more accurately depict the optimal location for an agribusiness firm providing precision agriculture technologies in the state of Ken- tucky. It was determined that the optimal solution was Muhlenberg County.

Dynamics of Land-Use Change in North Alabama: Implications of New Residential Development James Bukenya, Alabama A\&M University

The paper presents analytical tools for identifying potential impacts associated with land use change. The analysis outlines potential costs and benefits of land conversion activities to decision makers. The results show that loss of agricultural land erodes the county's ability to maintain revenue and cost equilibrium across selected land use types.

Long Term Financial Impacts of Drought Management Strategies Greg Kaase, Mac Young, Steven Klose, Joe Paschal, and Wayne Hanselka, Texas A\&M University

This paper analyzes the financial implications of drought management strategies for a model ranch in South Texas. The 2006 drought that affected Texas livestock producers left many cattlemen asking the age old question, "Should I cull to reduce my herd size or purchase feed to maintain my current herd?"

Reinforcing Agriculture Course Content: Lectures on Demand Joey Mehlhorn, Craig Darroch, Timothy Burcham, and Barbara Darroch, University of Tennessee

Student performance was compared for two sections of a freshman agribusiness class: traditional lecture versus a hybrid of traditional lecture and the ability to replay lectures using a streaming video server (Apreso Classroom $\left.^{\mathrm{TM}}\right)$. Initial observations indicate that having video lectures did not improve student performance.

TITLE: International Trade in Crops (Moderator: Osei Yeboah, North Carolina A\&T University) 
An Assessment of the Global Soybean Industry: An Application of the Stochastic Equilibrium Displacement Model Rafael Costa, Yan Xia, and C. Parr Rosson, Texas A\&M University

This study uses the stochastic equilibrium displacement model (SEDM) to investigate the impact on the soybean and its joint products (soy meal and soy oil) sectors of different countries and regions from transportation cost reduction in Brazil incorporating assumptions of decrease in the U.S. loan deficiency payment.

\section{Export Market Pricing Decisions and Market Power in World Grain Markets: A Duopoly Model for Soybeans Qiang Zhang, Michael Reed, and Sayed Saghaian, University of Kentucky}

This study investigates export pricing decisions and market power for soybeans using a duopoly model. The results from the pricing-to-market approach and residual demand elasticity approach show that soybean export markets are competitive. The continuous increase in world demand results in a positive relationship between export prices and volumes.
Market Integration in the North American Onion Markets: An Empirical Analysis Using Panel Data Dwi Susanto, C. Parr Rosson, and Flynn J. Adcock, Texas A\&M University

This study investigates the level of market integration in the North American onion markets. A two-sample period analysis suggests deeper market integration as NAFTA was fully implemented. Further analysis showed that U.S.-Canadian markets have experienced deeper market integration compared with U.S.-Mexican markets as well as Canadian-Mexican markets.

Testing the Market Integration in Regional Cantaloupe and Melon Markets between the United States and Mexico: An Application of Error Correction Model Yan Xia, Dwi Susanto, and C. Parr Rosson, Texas A\&M University

Examine the integration between U.S. and Mexican cantaloupe and watermelon prices using cointegration and error correction model approach. Cointegration analysis shows significant post-2002 improvement in market integration, particularly in the speed at which the market adjusts to departures from its longrun equilibrium. 